\title{
UJI AKTIVITAS ANTIRADIKAL BEBAS EKSTRAK ETANOL DAUN KEMANGI (Ocimum basilicum L.) DENGAN MENGGUNAKAN METODE DPPH
}

\author{
Linda Erviana ${ }^{1}$, Abd. Malik, dan Ahmad Najib \\ Fakultas Farmasi, Universitas Muslim Indonesia \\ 1lyndhaerviana@yahoo.com
}

\begin{abstract}
Basil leaves (Ocimum basilicum L.) the plant of the family Lamiaceae that can act as a free radical scavenger, flavonoid compounds. The aim of this research to determine and calculate the $I_{50}$ (Ocimum basilicum L.) that has activity as a free radical based on the binding free radical (1,1 diphenyl picryl-hydrazyl). Sample masceration with ethanol, where in the amount of the extract obtained is $10.16 \mathrm{gr}$. At the free radical scavenging test ethanol extract has moderate activity with $I_{50}$ value is $52.68 \mu \mathrm{g} / \mathrm{mL}$ lower than quercetin with $I_{50}$ value is 1.8 $\mu g / m L$.
\end{abstract}

Keywords: Ocimum basilicum L., extract ethanol, free radical scavenging

\section{PENDAhuluan}

Indonesia dikenal sebagai salah satu dari tujuh negara dengan keanekaragaman hayati terbesar dan memiliki potensi dalam pengembangan obat herbal dalam bidang kesehatan. Obat herbal yang biasa digunakan dimasyarakat adalah tanaman, yang menghasilkan senyawa metabolit sekunder. Salah satu senyawa metabolit sekunder pada tanaman adalah flavonoid, vitamin $\mathrm{C}$, betakaroten, asam urat, billirubin, dan albumin (Vaya \& Aviram, 2001).

Senyawa flavonoid yang terdapat pada tanaman memiliki aktivitas antioksidan alami yang dapat menangkap molekul radikal bebas atau sebagai antioksidan alami (Amic et al. 2003 \& Trisharyanti, 2012).

Salah satu tanaman yang memiliki senyawa flavonoid yaitu daun kemangi (Ocimum basilicum L.). Kandungan kimia yang terkandung yaitu tanin $(4,6 \%)$, flavonoid, steroid/triterpenoid, minyak atsiri (2\%), asam heksauronat, pentosa, xilosa, asam metil homoanisat, molludistin serta asam ursolat (Peter, 2002 dan Meyer, et al., 1982), flavonoid pada daun kemangi yaitu apigenin yang merupakan golongan flavon (Hariana, 2008) yang dapat digunakan sebagai antiradikal bebas.

Radikal bebas adalah senyawa kimia yang mempunyai satu atau lebih elektron tidak berpasangan. Senyawa ini bersifat tidak stabil dan sangat reaktif. Untuk mencapai kestabilan, molekul harus mencari elektron lain sebagai pasangan. Reaksi berantai ini dapat menimbulkan kerusakan sel yang berujung pada mutasi sel dan apabila merusak organ yang memiliki fungsi tertentu dapat menimbulkan penyakit degeneratif. Radikal bebas dalam kehidupan sehari-hari dapat dijumpai seperti akibat metabolisme yang berlebihan atau berasal dari lingkungan seperti asap rokok, polusi udara, bahan kimia beracun, pestisida serta radiasi sinar UV (Raharjo, 1992; Silalahi, 2001; Youngson, 2005).

Berdasarkan uraian diatas, maka akan dilakukan uji antiradikal bebas dengan menggunakan metode DPPH, dimana metode ini dipilih karena merupakan metode sederhana untuk evaluasi aktivitas antiradikal bebas (Amic et al., 2003).

\section{METODE PENELITIAN}

\section{A. Pengambilan dan Pengolahan Sampel}

Sampel daun kemangi (Ocimum basilicum L.) yang telah dikumpulkan, dicuci bersih terlebih dahulu, setelah itu dilakukan perajangan atau di potong-potong kecil. Selanjutnya, dikeringkan dengan cara diangin-anginkan tanpa paparan sinar matahari langsung, kemudian diserbukkan dan siap untuk diekstraksi (Dirjen POM, 1987).

\section{B. Pembuatan Sampel}

1. Ekstraksi secara maserasi pelarut etanol (Dirjen POM, 1987)

Ditimbang sampel daun kemangi (Ocimum basilicum L.) sebanyak 250 gram dimasukkan dalam wadah maserasi, tambahkan etanol $96 \%$ sebanyak 2 liter hingga simplisia tersebut terendam, dibiarkan selama 3 hari dalam bejana tertutup dan terlindung dari cahaya matahari sambil diaduk secara periodik, setelah 3 x 24 jam dilakukan penyaringan dan ampasnya dimaserasi kembali dengan cairan penyari yang baru. Maserasi dilakukan sebanyak 3 kali dan diperoleh ekstrak etanol cair. Hasil penyarian yang diperoleh kemudian diuapkan sehinnga diperoleh ekstrak etanol kental sebanyak 10,61 gram. 


\section{Uji Pendahuluan}

Pengujian dilakukan dengan cara sampel ekstrak etanol daun kemangi (Ocimum basilicum L.) dilarutkan dengan etanol 96\%, kemudian ditotolkan pada lempeng KLT dengan menggunakan pipa kapiler. Lempeng yang sudah ditotol dielusi dengan eluen n-heksan : etil asetat (7:3). Setelah dielusi diamati diprofil KLT pada beberapa penampak bercak yaitu sinar UV $254 \mathrm{~nm}, 366 \mathrm{~nm}$ dan dilanjutkan dengan penyemprotan DPPH.

\section{Uji Aktivitas pengikatan radikal bebas DPPH}

a. Pembuatan Larutan DPPH (Phongphaichit et al, 2007)

Larutan DPPH dibuat dengan cara menimbang DPPH sebanyak $5 \mathrm{mg}$ kemudian dilarutkan dengan $100 \mathrm{~mL}$ metanol absolut dalam labu tentukur dan diperoleh larutan DPPH dengan konsentrasi 50 ppm.

b. Pengukuran daya antioksidan blangko

Pengujian dilakukan dengan memipet 3,5 $\mathrm{mL}$ DPPH 50 ppm.Larutan ini kemudian dibiarkan selama 30 menit dan diukur absorbansinya pada panjang gelombang 514 $\mathrm{nm}$.

c. Pengukuran daya antioksidan ekstrak etanol daun kemangi (Ocimum basilicum L.)

Dibuat larutan stok $500 \mathrm{ppm}$ dengan cara menimbang ekstrak etanol daun kemangi (Ocimum basilicum L.) sebanyak $25 \mathrm{mg}$ dan dilarutkan dengan metanol absolut sambil diaduk dan dihomogenkan lalu cukupkan volumenya hingga $50 \mathrm{~mL}$. Selanjutnya dilakukan pengenceran :

1. Masing-masing larutan stok dipipet $0,2 \mathrm{~mL}$ kemudian dicukupkan dengan metanol absolut sampai volume akhir $5 \mathrm{~mL}(20$ ppm).

2. Masing-masing larutan stok dipipet $0,4 \mathrm{~mL}$ kemudian dicukupkan dengan metanol absolut sampai volume akhir $5 \mathrm{~mL}$ (40 ppm).

3. Masing-masing larutan stok dipipet $0,6 \mathrm{~mL}$ kemudian dicukupkan dengan metanol absolut sampai volume akhir $5 \mathrm{~mL}(60$ ppm).

4. Masing-masing larutan stok dipipet $0,8 \mathrm{~mL}$ kemudian dicukupkan dengan metanol absolut sampai volume akhir $5 \mathrm{~mL}$ (80 ppm).

5. Masing-masing larutan stok dipipet $1 \mathrm{~mL}$ kemudian dicukupkan dengan metanol absolut sampai volume akhir $5 \mathrm{~mL}(100$ ppm).

Pengujian dilakukan dengan memipet 0,5 $\mathrm{mL}$ larutan sampel dari berbagai konsentrasi. Kemudian masing-masing ditambahkan $3,5 \mathrm{~mL}$ DPPH 50 ppm. Campuran kemudian dihomogenkan dan dibiarkan pada suhu kamar selama 30 menit lalu serapannya diukur menggunakan spektrofotometer UV-Vis pada panjang gelombang $514 \mathrm{~nm}$.

d. Pengukuran aktivitas antiradikal bebas sampel pembanding (Kuersetin)

Dibuat larutan stok $50 \mathrm{ppm}$ dengan menimbang kuersetin setara $5 \mathrm{mg}$ kemudian dilarutkan dengan metanol absolut sambil diaduk dan dihomogenkan, lalu cukupkan volumenya hingga $100 \mathrm{~mL}$, kemudian dilakukan pengenceran :

1. Masing-masing larutan stok dipipet $0,2 \mathrm{~mL}$ kemudian dicukupkan dengan metanol absolut sampai volume akhir $5 \mathrm{~mL}$ (2 ppm).

2. Masing-masing larutan stok dipipet $0,4 \mathrm{~mL}$ kemudian dicukupkan dengan metanol absolut sampai volume akhir $5 \mathrm{~mL}$ (4 ppm).

3. Masing-masing larutan stok dipipet $0,6 \mathrm{~mL}$ kemudian dicukupkan dengan metanol absolut sampai volume akhir $5 \mathrm{~mL}$ (6 ppm).

4. Masing-masing larutan stok dipipet $0,8 \mathrm{~mL}$ kemudian dicukupkan dengan metanol absolut sampai volume akhir $5 \mathrm{~mL}$ (8 ppm).

5. Masing-masing larutan stok dipipet $1 \mathrm{~mL}$ kemudian dicukupkan dengan metanol absolut sampai volume akhir $5 \mathrm{~mL}$ (10 ppm).

Pengujian dilakukan dengan memipet 0,5 $\mathrm{mL}$ larutan sampel dari berbagai konsentrasi. Kemudian masing-masing ditambahkan $3,5 \mathrm{~mL}$ DPPH 50 ppm. Campuran kemudian dihomogenkan dan dibiarkan pada suhu kamar selama 30 menit lalu serapannya diukur pada panjang gelombang $514 \mathrm{~nm}$.

Aktivitas penangkap radikal DPPH (\%) dihitung dengan rumus berikut :

$\%$ Pengikatan radikal bebas

$$
=\frac{(\text { Abs standar-Abs sampel })}{\text { Abs standar }} \times 100 \%
$$

Data aktivitas antioksidan penangkap radikal DPPH dianalisis dan masing-masing dihitung nilai $\mathrm{IC}_{50}$ melalui analisis probit. $\mathrm{IC}_{50}$ adalah konsentrasi yang mampu menghambat 50\% DPPH 


\section{HASIL DAN PEMBAHASAN}

Simplisia Daun Kemangi (Ocimum Basilicum L.) diekstraksi dengan menggunakan metode maserasi, dimana merupakan salah satu metode ekstraksi dingin (Tobo, 2001). Metode ini tidak merusak komponen kimia karena tidak adanya pemanasan dalam proses ekstraksi serta pengerjaan dan peralatan yang digunakan sederhana dan mudah diusahakan (Adrian, 2000).

Maserasi sampel dilakukan dengan menggunakan pelarut etanol karena sifatnya yang mampu melarutkan hampir semua zat, baik yang bersifat polar, semi polar dan non polar serta kemampuannya untuk mengendapkan protein dan menghambat kerja enzim sehingga dapat terhindar proses hidrolisis dan oksidasi (Helmi, 2006).

Rendamen adalah persentase perbandingan antara berat bagian ekstrak dengan berat total sampel awal yang digunakan. Hasil rendamen yang diperoleh dari $250 \mathrm{~g}$ dalam $4000 \mathrm{~mL}$ etanol $96 \%$ yaitu $4,24 \%$.

Penelitian ini dilakukan dengan pengujian secara kuantitatif dan secara kualitatif. Pengujian aktivitas antiradikal bebas secara kualitatif dengan menggunakan lempeng KLT. Setelah lempeng dielusi kemudian disemprot dengan DPPH, menghasilkan warna kuning dengan latar belakang berwarna ungu pada nilai $\mathrm{Rf} 0,563$ dan 0,8 . Sedangkan pada penampak bercak $\mathrm{AlCl}_{3}$ menghasilkan warna kuning pada nilai $\operatorname{Rf} 0,563$. Hal ini dikerekan terjadinya reaksi antara $\mathrm{AlCl}_{3}$ dengan flavonoid membentuk kompleks antara gugus hidroksil dan keton yang bertetangga atau dengan gugus hidroksil yang saling bertetangga.

Serbuk kristal DPPH yang akan disemprotkan pada lempeng KLT dilarutkan terlebih dahulu dengan menggunakan metanol. Metanol dipilh sebagai pelarut karena metanol dapat melarutkan Kristal DPPH dan juga memiliki sifat yang dapat melarutkan komponen non polar (Apriandi, 2011). Larutan DPPH yang awalnya berwarna ungu setelah bereaksi dengan antioksidan alami akan membentuk warna kuning dengan latar belakang ungu pada saat penyemprotan. Semakin tinggi kandungan antioksidan maka warna ungu pada larutan DPPH akan semakin berkurang dan membentuk warna kuning (Molyneux, 2004).

Tabel 1. Data \% rendamen ekstrak daun kemangi (Ocimum basilicum L.)

\begin{tabular}{cccc}
\hline $\begin{array}{c}\text { Jenis } \\
\text { pelarut }\end{array}$ & $\begin{array}{c}\text { Berat } \\
\text { sampel } \\
\text { kering (g) }\end{array}$ & $\begin{array}{c}\text { Berat } \\
\text { Ekstrak (g) }\end{array}$ & $\begin{array}{c}\text { Rendamen } \\
(\%)\end{array}$ \\
\hline $\begin{array}{c}\text { Etanol } \\
96 \%\end{array}$ & 250 & 10,61 & 4,24 \\
\hline
\end{tabular}

Tabel 2. Nila Rf profil KLT sebelum dan sesudah penyemprotan DPPH

\begin{tabular}{ccc}
\hline $\begin{array}{c}\text { Penampak } \\
\text { bercak }\end{array}$ & Nilai Rf & Warna Noda \\
\hline UV 254 & 0,309 & hijau \\
& 0,381 & hijau \\
& 0,418 & kuning \\
& 0,854 & kuning \\
& 0,872 & hijau \\
UV 366 & 0,309 & kuning \\
& 0.4 & hijau \\
& 0,563 & kuning \\
& 0,581 & hijau \\
& 0,818 & hijau \\
& 0,854 & hijau \\
DPPH & 0,563 & kuning \\
& 0,8 & kuning \\
$\mathrm{AlCl}_{3}$ & 0,563 & kuning \\
& 0,6 & hijau \\
& 0,854 & hijau \\
\hline
\end{tabular}

Pengujian secara kuantitatif dengan menggunakan spektrofotometer UV-Vis yaitu dengan membuat larutan stok $500 \mathrm{ppm}$, dari larutan stok tersebut dibuat lima konsentrasi $(20,40,60,80$, dan 100) ppm. Kemudian dipipet $0,5 \mathrm{~mL}$ larutan sampel dari kelima konsentrasi dan ditambahkan 3,5 mL DPPH 50 ppm. Selanjutnya campuran dihomogenkan dan dibiarkan selama 30 menit dengan tujuan agar sampel dapat bereaksi dengan sempurna dengan $\mathrm{DPPH}$

Metode uji aktivitas antiradikal bebas dengan menggunakan radikal bebas DPPH. Metode DPPH dipilih karena memiliki beberapa kelebihan antara lain sederhana, mudah, cepat, peka, serta memerlukan sedikit sampel. Parameter yang digunakan untuk mengetahui aktivitas antioksidan adalah $\mathrm{IC}_{50}$ yang didefinisikan sebagai konsentrasi senyawa antioksidan yang menyebabkan hilangnya $50 \%$ aktivitas DPPH (Molyneux, 2004).

Shahidi dan Naczk (1995) mengemukakan bahwa senyawa yang tergolong antioksidan alami dari golongan senyawa fenolik seperti senyawa fenolik sederhana, flavonoid dan tanin. Senyawa flavonoid, fenolik sederhana dan tanin merupakan senyawa antioksidan yang mengandung struktur fenol dan memiliki beberapa gugus fungsi hidroksi yang banyak terdapat dalam tanaman. Senyawa non fenolik yang dapat memiliki aktivitas antioksidan antara lain alkaloid, minyak atsiri, dan saponin. Hal ini sesuai dengan penelitian terdahulu yang menyatakan adanya senyawa alkaloid dan saponin dalam tanaman Graptophylum pictum Griff dan Gynura procumbens Merr. (Ozaki dkk., 1989) serta adanya kandungan 
minyak atsiri dalam Ocimum basilicum (Viera dan simon, 2000).

Perhitungan yang digunakan dalam penentuan aktivitas penangkap radikal adalah nilai $\mathrm{IC}_{50}$ (Inhibitor Concentration 50\%) nilai tersebut menggambarkan besarnya konsentrasi senyawa uji yang dapat menangkap radikal sebesar $50 \%$. Nilai $\mathrm{IC}_{50}$ diperoleh dengan menggunakan persamaan regrasi linier yang menyatakan hubungan antara konsentrasi sampel (senyawa uji) dengan simbol X terhadap aktivitas penangkapan radikal rata-rata dengan simbol $\mathrm{Y}$ dari seri replikasi pengukuran. Semakin kecil nlai $\mathrm{IC}_{50}$ maka senyawa tersebut mempunyai keefektifan sebagai penangkap radikal lebih baik.

Hasil penelitian ekstrak etanol daun kemangi (Ocimum basilicum L.) memiliki aktivitas sedang dengan nilai $\mathrm{IC}_{50} 52,68 \mu \mathrm{g} / \mathrm{mL}$, sedangkan kuersetin memiliki aktivitas sangat kuat dengan nilai $\mathrm{IC}_{50} \quad 1,8$ $\mu \mathrm{g} / \mathrm{mL}$. Menurut Phongpaichit et al (2007), suatu senyawa dikatakan sebagai antiradikal bebas sangat kuat apabila nilai $\mathrm{IC}_{50}<10 \mu \mathrm{g} / \mathrm{mL}$, kuat apabila nilai $\mathrm{IC}_{50}$ antara $10-50 \mu \mathrm{g} / \mathrm{mL}$, sedang apabila nilai $\mathrm{IC}_{50}$ berkisar antara 50-100 $\mu \mathrm{g} / \mathrm{mL}$, lemah apabila nilai $\mathrm{IC}_{50}$ berkisar antara $100-250 \mu \mathrm{g} / \mathrm{mL}$ dan tidak aktif apabila $\mathrm{IC}_{50} \operatorname{diatas} 250 \mu \mathrm{g} / \mathrm{mL}$.

Tabel 3. Perhitungan $\%$ pengikatan radikal bebas ekstrak etanol daun Kemangi (Ocimum basilicum L.)

\begin{tabular}{ccccc}
\hline Sampel & $\begin{array}{c}\text { Konsentrasi } \\
(\mathrm{ppm})\end{array}$ & $\begin{array}{c}\text { Absorban } \\
\text { sampel }\end{array}$ & $\begin{array}{c}\text { \%peredaman } \\
\text { Radikal bebas }\end{array}$ & $\begin{array}{c}\text { IC } \\
50\end{array}$ \\
\hline Ekstrak & 2,5 & 1,002 & 9,81 & \\
Etanol & 5 & 0,965 & 13,14 & 52 \\
daun & 7,5 & 0,951 & 14,40 &, \\
kemangi & 10 & 0,924 & 16,83 & 68 \\
& 12,5 & 0,913 & 17,82 & \\
\hline
\end{tabular}

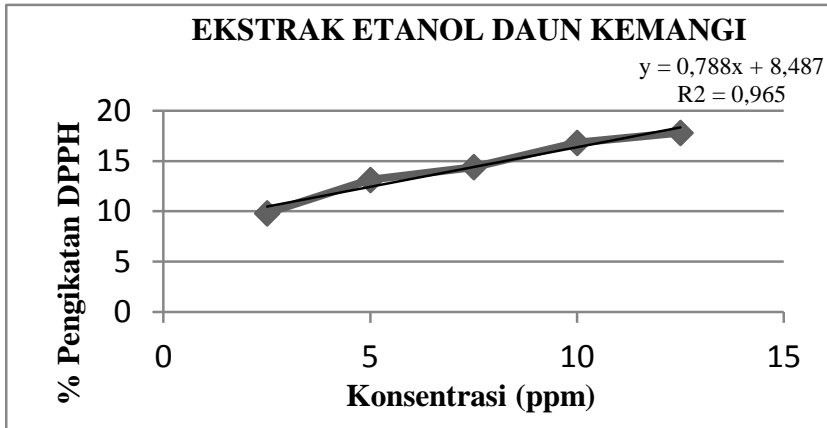

Gambar 1. Grafik hubungan antara kensentrasi ekstrak etanol daun kemangi (Ocimum basilicum L.) dengan \% pengikatan DPPH

Tabel 4. Perhitungan $\%$ pengikatan radikal bebas sampel pembanding kuersetin

\begin{tabular}{ccccc}
\hline Sampel & $\begin{array}{c}\text { konsentrasi } \\
\text { (ppm) }\end{array}$ & $\begin{array}{c}\text { Absorbansi } \\
\text { sampel }\end{array}$ & $\begin{array}{c}\text { \%peredaman } \\
\text { Radikal } \\
\text { bebas }\end{array}$ & IC $_{\text {50 }}$ \\
\hline \multirow{3}{*}{ Kuersetin } & 0,25 & 0,954 & 14,131 & \\
& 0,5 & 0,878 & 20,972 & \\
& 0,75 & 0,851 & 23,402 & 1,8 \\
& 1 & 0,787 & 29,163 & \\
\hline
\end{tabular}

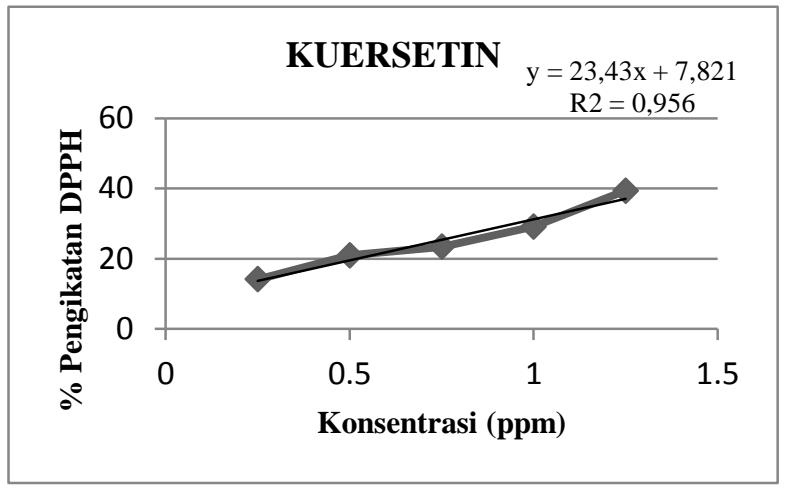

Gambar 2. Grafik hubungan antara konsentrasi kuersetin dengan \% pengikatan DPPH

\section{KESIMPULAN}

Berdasarkan hasil penelitian yang dilakukan dapat disimpulkan bahwa ekstrak etanol daun kemangi (Ocimum basilicum L.) memiliki aktivitas antioksidan sedang dengan nilai $\mathrm{IC}_{50} 52,68 \mu \mathrm{g} / \mathrm{mL}$.

\section{DAFTAR PUSTAKA}

Adrian, M., 2000. Teknik Kromatografi . Penerbit Andi, Yogyakarta.

Amic, D., Beslo, D., Trinajstic, N., Davidovic. 2003. Structure-Radical Scavenging Activity Relationships of Flavonoids. Croatia Chem Acta 76

Apriandi, A. 2011. Aktivitas Antioksidan dan Komponen Bioaktif Keong Ipong-ipong (Fasciolaria salmo).(Skripsi). Bogor: Fakultas Perikanan dan Ilmu Kelautan. Institut Pertanian Bogor

Direktorat Jendral Pengawasan Obat dan Makanan.1987. Analisis Obat Tradisional, Jilid I. Departemen Kesehatan RI, Jakarta

Hariana, A., 2008. Tumbuhan Obat \& Khasiatnya. Penerbit: Penebar Swadaya. Jakarta.

Meyer, N, 1982. Brine shrimp: a convenient general bioassay for active plant constituents. Planta Med May (Online): http://www.ncbi.nlm.nih.gov/pubmed/173967 75. diakses tanggal 17 Oktober 2013.

Molyneux, P., 2004, The Use of Stable Free Radical Diphenylpicrylhydrazyl (DPPH) for 
Estimating Antioxidant Activity, J. Sci. Tecnol.

Peter. 2002. Herbal remedies. (Online): http://content.nejm.org/cgi/reprint/347/25/204 6.pdf. diakses tanggal 17 Oktober 2013.

Phongphaichit, S., Nikom, J., Rungjindamai N., Jariya, S., 2007. Biological activities of extract from endophytic fungi isolated from Garcinia plants, FEMS Immunol Med Microbial.

Raharjo, M., 1992, Tanaman Berkhasiat Antioksidan, Penebar Swadaya, Jakarta.

Silalahi, J. 2006. Makanan Fungsional. Yogyakarta: Kanisius

Tobo, F., 2001, Buku Pegangan Laboratorium Fitokimia I, Fakultas MIPA, Universitas Hasanuddin, Makassar.

Vaya, J, Aviram, M. 2001. Nutritional antioxidant : mechanism of action, analyses of activities and medical applications, Curr. Med. ChemImm,Endoc. \&Metab Agents.

Youngson, R. 2003, Antioksidan Manfaat Vitamin C Dan E Bagi Kesehatan, Arca : Jakarta. 